\title{
Synthesis of thiophene-linked pyrimidopyrimidines as pharmaceutical leads
}

\author{
M B SIDDESH, BASAVARAJ PADMASHALI*, K S THRIVENI and C SANDEEP \\ Department of Chemistry, Sahyadri Science College (Autonomous), Kuvempu University, \\ Shimoga 577 203, India \\ e-mail: basavarajpadmashali@yahoo.com
}

MS received 14 June 2013; revised 3 December 2013; accepted 10 December 2013

\begin{abstract}
Thiophene-substituted chalcones were cyclised with guanidine in the presence of potassium hydroxide to get 4-substituted-6-thiophenopyrimidines $\mathbf{2 a - e}$ which were then refluxed with acetylacetone to obtain pyrimidopyrimidines 3a-e. Compounds $\mathbf{2 a - e}$ were also refluxed with ethylacetoacetate to afford pyirmidopyirimidines 4a-e which on refluxing with $\mathrm{POCl}_{3}$ in presence of DMF produced compounds 5a-e. Nucleophilic substitution reactions on 5a-e were carried out with aniline to obtain 6a-e. The structures of the newly synthesised compounds have been confirmed by elemental analysis and spectral studies. Some selected compounds have been screened for antibacterial and analgesic activities.
\end{abstract}

Keywords. 2-Acetylthiophene; chalcones; guanidine hydrochloride; pyrimidopyrimidines.

\section{Introduction}

Pyrimidines have a long and distinguished history extending from the days of their discovery as important constituents of nucleic acids to their current use in chemotherapy of AIDS. Pyrimidine nucleus occurs in biologically important products such as nucleic acids, vitamins, coenzymes and pharmacologically useful natural products of plant origin. Pyrimidines are an important class of heterocyclic compounds, which possess a wide range of biological activities such as anticancer, ${ }^{1,2}$ antibacterial, ${ }^{3}$ anti-inflammatory, ${ }^{4}$ antiviral, ${ }^{5}$ antitubercular, ${ }^{6}$ antihypertensive ${ }^{7}$ and anticonvulsant ${ }^{8}$ activities.

The pyrimidopyrimidine moiety represents a core structure that is a useful template for the design of a variety of tyrosine kinase inhibitors. ${ }^{9}$ From high throughput screening, a pyrimidopyrimidine analogue was identified as a dual inhibitor of the growth factor receptors. This analogue was a significantly less potent inhibitor of the other tested kinases.

In a programme to design and develop mechanismbased compounds active as substrates and inhibitors of dihydrofolate reductase (DHFR), Gebauer et al. ${ }^{10}$ have reported the synthesis and physical properties of the 6-methyl, 8-methyl and 8-ethyl derivatives of the parent 2-aminopyrimido[4,5-d]pyrimidin-4- $(3 \mathrm{H})$ one. These compounds are the first members of a class

*For correspondence of heterocycles related to 8-alkylpterins (N8-alkyl-2aminopteridin-4(8H)-ones), which have been shown to be novel substrates for DHFR.

Although various procedures for synthesis of pyrimidine derivatives have been developed, it is convenient to synthesize substituted pyrimidines by the reaction of amidine or guanidine derivatives with a variety of 1, 3-dielectrophilic three-carbon units such as $\alpha, \beta$ unsaturated carbonyl compounds. ${ }^{11}$

\section{Experimental section}

All the melting points were determined in an open capillary and were uncorrected. IR spectra were recorded on Bruker alpha FT IR spectrophotometer, ${ }^{1} \mathrm{H}$ NMR spectra were measured on Bruker AV $400 \mathrm{MHZ}$ using $\mathrm{CDCl}_{3}$ and DMSO as solvent. Chemical shifts are expressed in $\delta$ ppm. Mass spectra were performed on a Joel JMS-D 300 mass spectrometer operating at $70 \mathrm{eV}$. All the reactions were followed and checked by TLC, and further purification was done by column chromatography. All the reagents used were of AR grade and they were again purified by distillation.

\subsection{Preparation of (2E)-3-(4-methoxyphenyl)-1- (thiophen-2-yl) prop-2-en-1-one (1a)}

A mixture of 2-acetylthiophene (1.26 g, $0.01 \mathrm{~mol})$ and anisaldehyde (1.36 g, $0.01 \mathrm{~mol})$ were stirred in ethanol $(15 \mathrm{~mL})$, then an aqueous solution of $40 \%$ potassium 
hydroxide $(10 \mathrm{~mL})$ was added and stirring was continued for $2 \mathrm{~h}$. The mixture was kept overnight at room temperature, reaction mixture was poured into crushed ice and then acidified with dilute hydrochloric acid. The solid separated was filtered and recrystalized from ethyl acetate, ethanol mixture (8:2). Similarly, the compounds $\mathbf{1 b}-\mathbf{e}$ were prepared.

2.1a 2E)-3-(4-Methoxyphenyl)-1-(thiophen-2-yl)prop -2-en-1-one (1a): IR (KBr) $\quad\left(v_{\max } \quad \mathrm{cm}^{-1}\right): 1614$ $(\mathrm{CH}=\mathrm{CH}), \quad 1644 \quad(\mathrm{C}=\mathrm{O}) ;{ }^{1} \mathrm{H}$ NMR $\left(400 \mathrm{MH}_{\mathrm{Z}}\right.$, $\left.\mathrm{CDCl}_{3}\right) \quad \delta(\mathrm{ppm}): 8.05(\mathrm{~m}, 2 \mathrm{H} \mathrm{Ar} \mathrm{H}), 7.70(\mathrm{~d}, 2 \mathrm{H}$, Ar H), 7.25 (m,1H, Ar H), 6.99 (d, 2H, Ar H), 6.93 $(\mathrm{dd}, 2 \mathrm{H}, \mathrm{CH}=\mathrm{CH}), 3.87\left(\mathrm{~s}, 3 \mathrm{H}, \mathrm{OCH}_{3}\right) ; \mathrm{MS}: \mathrm{m} / \mathrm{z}$ 245.Calcd. (\%) for $\mathrm{C}_{14} \mathrm{H}_{12} \mathrm{O}_{2} \mathrm{~S}: \mathrm{C}, 68.57 ; \mathrm{H}, 4.89$; Found: C, 68.53; H, 4.85 .

2.2 Preparation of 4-(4-methoxyphenyl)-6-(thiophen2-yl) pyrimidine-2-amine (2a)

A mixture of chalcone (2E)-3-(4-methoxyphenyl)-1(thiophen-2-yl)prop-2-en-1-one $\mathbf{1 a}(2.44 \mathrm{~g}, 0.01 \mathrm{~mol})$ and guanidine hydrochloride $(0.96 \mathrm{~g}, 0.01 \mathrm{~mol})$ in 1,4dioxane $(15 \mathrm{~mL})$ was refluxed on water bath for 5 h. ${ }^{12}$ The solvent was completely evaporated and the residue was poured into ice cold water. The precipitated solid was collected by filtration, purified on silica gel column using ethyl acetate and petroleum ether mixture (2:8) solvent system. Similarly, the compounds $\mathbf{2 b - e}$ were prepared.

2.2a 4-(4-Methoxyphenyl)-6-(thiophen-2-yl) pyrimidine-2-amine (2a): IR $(\mathrm{KBr})\left(v_{\max } \mathrm{cm}^{-1}\right): 3330(\mathrm{~N}$ $\mathrm{H}), 1297-1176$ (C-O-C); ${ }^{1} \mathrm{H}$ NMR $\left(400 \mathrm{MH}_{\mathrm{Z}}, \mathrm{CDCl}_{3}\right) \delta$ (ppm): 5.09 (s, 2H, $\mathrm{NH}_{2}$ ), 8.03 (s, 1H Ar H), 7.90 (d, $2 \mathrm{H}, \operatorname{Ar} \mathrm{H}), 7.55(\mathrm{~m}, 2 \mathrm{H}, \operatorname{Ar} \mathrm{H}), 6.99(\mathrm{~m}, 3 \mathrm{H}, \operatorname{Ar} \mathrm{H})$, $3.88\left(\mathrm{~s}, 3 \mathrm{H}, \mathrm{OCH}_{3}\right) 7$; MS m/z: 284. Calcd. (\%) for $\mathrm{C}_{15} \mathrm{H}_{13} \mathrm{~N}_{3} \mathrm{OS}$ : C, 63.38; H, 4.57; N, 14.78; Found: C, $63.27 ; \mathrm{H}, 4.55 ; \mathrm{N}, 14.86$.

\subsection{Preparation of 2-(4-methoxyphenyl)-6,8-} dimethyl-4-(thiophen-2-yl)-4H-pyrimido [1,2-a]pyrimidine (3a)

4-(4-Methoxyphenyl)-6-(thiophen-2-yl)pyrimidine2-amine (2a) $(2.84 \mathrm{~g}, 0.01 \mathrm{~mol})$ and acetyl acetone $(0.1 \mathrm{~g}, 0.01 \mathrm{~mol})$ in catalytic amount of acetic acid ${ }^{13}$ were taken in a round bottomed flask and refluxed for $10 \mathrm{~h}$. The reaction was monitored by TLC, the reaction mixture was then poured into crushed ice. The product obtained was filtered, washed, dried and recrystalized using ethanol. Similarly, the compounds $\mathbf{3 b}$-e were prepared.

2.3a 2-(4-Methoxyphenyl)-6,8-dimethyl-4-(thiophen2-yl)-4H-pyrimido[1,2-a]pyrimidine (3a): IR ( $\mathrm{KBr})$ $v\left(\mathrm{~cm}^{-1}\right): 1247(\mathrm{C}-\mathrm{O}-\mathrm{C}) ; 1607(\mathrm{C}=\mathrm{N}), 817(\mathrm{C}-\mathrm{S}-\mathrm{C})$; ${ }^{1} \mathrm{H}$ NMR $\left(400 \mathrm{MH}_{\mathrm{Z}}, \mathrm{CDCl}_{3}\right) \delta$ (ppm): 2.03-2.17 (s, 6H, $\left.2 \mathrm{CH}_{3}\right), 8.09$ (s, $\left.1 \mathrm{H} \mathrm{Ar} \mathrm{H}\right), 7.90(\mathrm{~m}, 3 \mathrm{H}, \mathrm{Ar} \mathrm{H}), 7.58$ (m,2H, Ar H), 6.85 (m, 3H, Ar H), 3.88 (s, 3H, $\mathrm{OCH}_{3}$ ); MS m/z: 350. Calcd. (\%) for $\mathrm{C}_{20} \mathrm{H}_{19} \mathrm{~N}_{3} \mathrm{OS}: \mathrm{C}, 68.57$; H, 5.42; N, 12.00; Found: C, 68.51; H, 5.35; N, 11.94 .

\subsection{Preparation of 2-(4-methoxyphenyl)-8-methyl-4- (thiophen-2-yl)-4H-pyrimido[1,2-a]pyrimidin-6-ol (4a)}

4-(4-Methoxyphenyl)-6-(thiophen-2-yl)pyrimidine-2amine (2a) $(2.84 \mathrm{~g}, 0.01 \mathrm{~mol})$ and ethylacetoacetate $(0.13 \mathrm{~g}, 0.01 \mathrm{~mol})$ in catalytic amount of acetic acid were taken in a round bottomed flask and the reaction mixture was refluxed for $6 \mathrm{~h}$. The reaction was monitored by TLC. The mixture was then poured into crushed ice. The solid separated was filtered, dried and recrystalized using ethanol, ehylacetate mixture. Similarly, the compounds $\mathbf{4 b - e}$ were prepared.

Table 1. Characterisation data of synthesised compounds.

\begin{tabular}{|c|c|c|c|c|}
\hline Sl. No. & Comp. & Nature & Yield (\%) & $\mathrm{mp}\left({ }^{\circ} \mathrm{C}\right)$ \\
\hline 1 & $2 \mathbf{a}$ & Crystalline & 83 & $232-235$ \\
\hline 2 & $2 b$ & Crystalline & 71 & $246-232$ \\
\hline 3 & $2 \mathrm{c}$ & Crystalline & 75 & 254-261 \\
\hline 4 & $2 d$ & Crystalline & 89 & $264-270$ \\
\hline 5 & $2 e$ & Crystalline & 72 & 239-244 \\
\hline 6 & $3 \mathbf{a}$ & Crystalline & 74 & $233-240$ \\
\hline 7 & $3 \mathbf{b}$ & Crystalline & 62 & $242-247$ \\
\hline 8 & $3 c$ & Crystalline & 49 & $257-260$ \\
\hline 9 & 3d & Crystalline & 60 & $228-235$ \\
\hline 10 & $3 \mathbf{e}$ & Crystalline & 52 & $222-225$ \\
\hline 11 & $4 \mathbf{a}$ & Crystalline & 55 & $266-272$ \\
\hline 12 & $4 b$ & Crystalline & 68 & $255-261$ \\
\hline 13 & $4 c$ & Crystalline & 60 & $259-265$ \\
\hline 14 & $4 d$ & Crystalline & 63 & $270-278$ \\
\hline 15 & $4 e$ & Crystalline & 51 & $277-282$ \\
\hline 16 & $5 \mathbf{a}$ & Crystalline & 58 & $241-248$ \\
\hline 17 & $5 b$ & Crystalline & 48 & 234-239 \\
\hline 18 & $5 c$ & Crystalline & 57 & $265-270$ \\
\hline 19 & $5 d$ & Crystalline & 43 & $270-277$ \\
\hline 20 & $5 e$ & Crystalline & 49 & $278-280$ \\
\hline 21 & $\mathbf{6 a}$ & Crystalline & 62 & $275-280$ \\
\hline 22 & $6 b$ & Crystalline & 55 & $263-268$ \\
\hline 23 & $6 c$ & Crystalline & 50 & $271-276$ \\
\hline 24 & 6d & Crystalline & 61 & $254-260$ \\
\hline 25 & $6 e$ & Crystalline & 60 & $266-271$ \\
\hline
\end{tabular}


2.4a 2-(4-Methoxyphenyl)-8-methyl-4-(thiophen-2yl)-4H-pyrimido[1,2-a]pyrimidin-6-ol $(4 \boldsymbol{a}): \quad \mathrm{IR}(\mathrm{KBr})$ $\left(v_{\max } \mathrm{cm}^{-1}\right): 3323(\mathrm{OH}), 1607(\mathrm{C}=\mathrm{N}) ;{ }^{1} \mathrm{H}$ NMR $(400$ $\left.\mathrm{MH}_{\mathrm{Z}}, \mathrm{CDCl}_{3}\right) \quad \delta(\mathrm{ppm}): 1.21\left(\mathrm{~s}, 3 \mathrm{H}, \mathrm{CH}_{3}\right), 9.48(\mathrm{~s}$, $1 \mathrm{H}, \mathrm{OH}), 8.02(\mathrm{~s}, 1 \mathrm{H}$ Ar H), $7.93(\mathrm{~m}, 3 \mathrm{H}, \operatorname{Ar} \mathrm{H})$, 7.59 (m,2H, Ar H), 6.90 (m, 3H, Ar H), 3.88 (s, 3H, $\mathrm{OCH}_{3}$ ); MS m/z: 351. Calcd. (\%) for $\mathrm{C}_{19} \mathrm{H}_{17} \mathrm{~N}_{3} \mathrm{O}_{2} \mathrm{~S}: \mathrm{C}$, 64.95; H, 4.84; N, 11.96; Found: C, 64.90; H, 4.78; N, 11.99.

\subsection{Preparation of 6-chloro-2-(4-methoxyphenyl)-8-} methyl-4-(thiophen-2-yl)-4H-pyrimido[1,2a]pyrimidine $(5 \boldsymbol{a})$

A mixture of 2-(4-methoxyphenyl)-8-methyl-4-(thiophen-2-yl)-1,9a-dihydro-4H-pyrimido[1,2-a]pyrimidin6-ol (4a) (3.51 g, $0.01 \mathrm{~mol}$ ) and phosphoryl chloride
$(4.5 \mathrm{~g}, 0.03 \mathrm{~mol})$ in dimethyl formamide $(10 \mathrm{~mL})$ were refluxed on a heating mantle for $5 \mathrm{~h}$. Then the reaction mixture was cooled and poured into crushed ice. The solid separated was filtered, dried and recrystalized using chloroform-hexane. Similarly, the compounds 5b-e were prepared.

2.5a 6-Chloro-2-(4-methoxyphenyl)-8-methyl-4(thiophen-2-yl)-4H-pyrimido[1,2-a] pyrimidine (5a): IR (KBr) $\left(v_{\max } \mathrm{cm}^{-1}\right): 724(\mathrm{C}-\mathrm{Cl}), 830(\mathrm{C}-\mathrm{S}-\mathrm{C}) ; 1650$ $(\mathrm{C}=\mathrm{N}) ;{ }^{1} \mathrm{H}$ NMR $\left(400 \mathrm{MH}_{\mathrm{Z}}, \mathrm{CDCl}_{3}\right) \quad \delta(\mathrm{ppm}): 1.26$ (s, 3H, $\left.\mathrm{CH}_{3}\right), 8.14$ (s, $\left.1 \mathrm{H} \mathrm{Ar} \mathrm{H}\right), 7.99(\mathrm{~m}, 3 \mathrm{H}, \mathrm{Ar} \mathrm{H})$, $7.69(\mathrm{~m}, 2 \mathrm{H}, \operatorname{Ar} \mathrm{H}), 7.25$ (m, 3H, Ar H), 3.80 (s, 3H, $\mathrm{OCH}_{3}$ ); MS m/z: 370. Calcd. (\%) for $\mathrm{C}_{19} \mathrm{H}_{16} \mathrm{ClN}_{3} \mathrm{OS}$ : C, 61.62; H, 4.32; N, 11.35; Found: C, 61.58; H, 4.31; $\mathrm{N}, 11.29$.

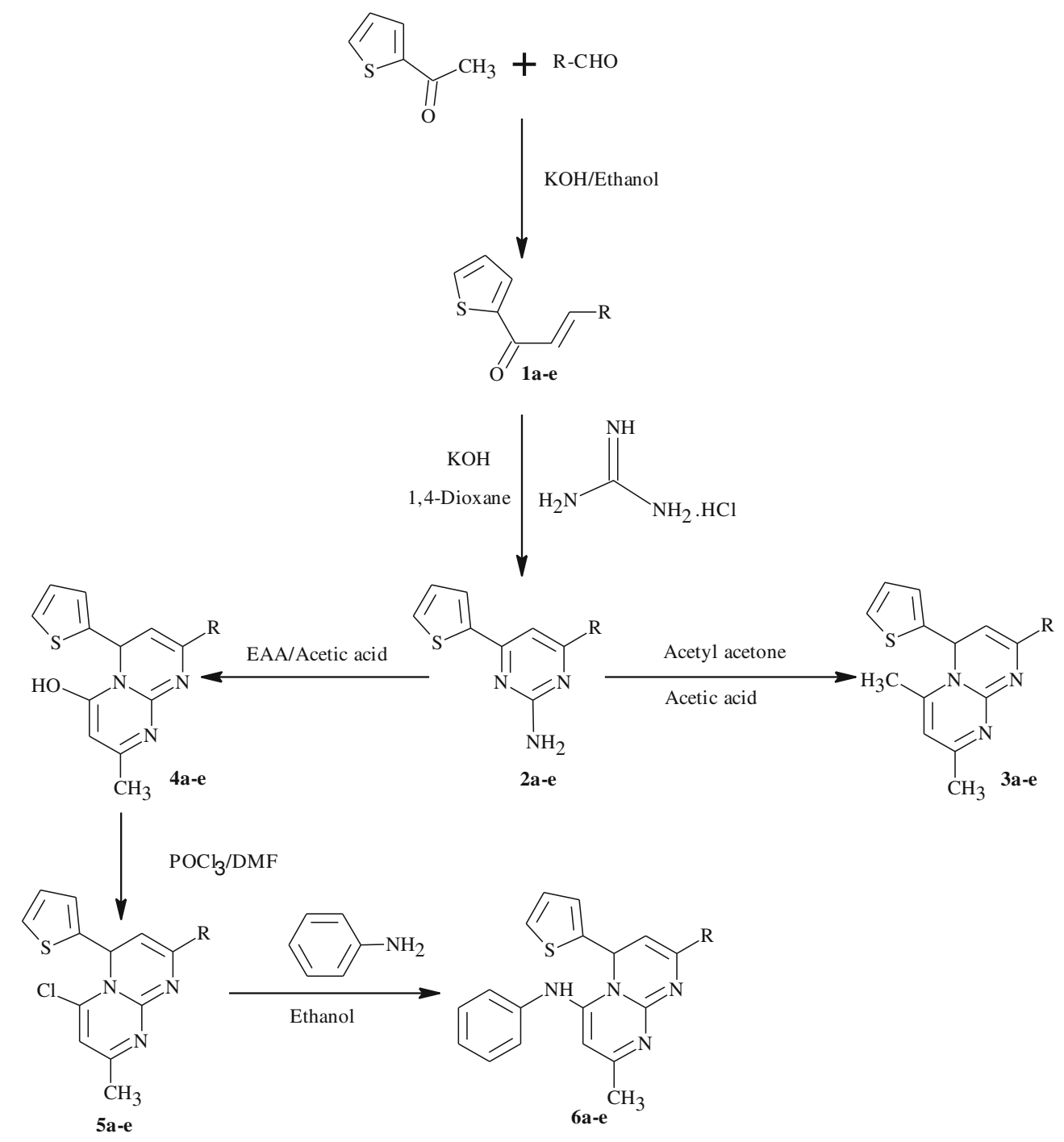

Scheme 1. General synthetic procedure for 4-substituted-4-(thiophene-2-yl)-pyrimido [1,2- $a]$ pyrimidines 3a-e and 4-substituted-6-(thiophene-2-yl)-pyrimido[1,2-a]pyrimidin-4amine $\mathbf{6 a - e .}$ 
2.6 Preparation of 8-(4-methoxyphenyl)-2-methyl-Nphenyl-6-(thiophen-2-yl)-6H-pyrimido[1,2-

a]pyrimidin-4-amine (6a)

A mixture of 6-chloro-2-(4-methoxyphenyl)-8-methyl4-(thiophen-2-yl)-1,9a-dihydro-4H pyrimido[1,2- $a$ ]pyrimidine $5 \mathrm{a}(3.7 \mathrm{~g}, 0.01 \mathrm{~mol})$ and aniline $(0.93 \mathrm{~g}$, $0.01 \mathrm{~mol})$ in ethanol $(15 \mathrm{~mL})$ media was refluxed for $2 \mathrm{~h}$. The reaction mixture was cooled and poured into crushed ice. The solid obtained was filtered and recrystalized using ethanol. Similarly, the compounds $\mathbf{6 b}-\mathbf{e}$ were prepared.

2.6a 8-(4-Methoxyphenyl)-2-methyl-N-phenyl-6(thiophen-2-yl)-6H-pyrimido[1,2-a]pyrimidin-4-amine (6a): $\quad \operatorname{IR}(\mathrm{KBr})\left(v_{\max } \mathrm{cm}^{-1}\right): 3300(\mathrm{NH}), 1638(\mathrm{C}=\mathrm{N})$; ${ }^{1} \mathrm{H}$ NMR $\left(400 \mathrm{MH}_{\mathrm{Z}}, \mathrm{CDCl}_{3}\right) \quad \delta$ (ppm): 1.58 (s, 3H, $\left.\mathrm{CH}_{3}\right), 5.13(\mathrm{~s}, 2 \mathrm{H}, \mathrm{NH}) ; 8.24(\mathrm{~m}, 3 \mathrm{H} \mathrm{Ar} \mathrm{H}), 7.99$ $(\mathrm{m}, 4 \mathrm{H}, \operatorname{Ar} \mathrm{H}), 7.62(\mathrm{~m}, 3 \mathrm{H}, \mathrm{Ar} \mathrm{H}), 7.15(\mathrm{~m}, 4 \mathrm{H}, \mathrm{Ar}$ $\mathrm{H}), 3.80\left(\mathrm{~s}, 3 \mathrm{H}, \mathrm{OCH}_{3}\right)$; MS m/z: 427. Calcd. (\%) for $\mathrm{C}_{25} \mathrm{H}_{22} \mathrm{~N}_{4} \mathrm{OS}$ : C, 59.40; H, 4.15; N, 11.08; Found: C, $59.30 ; \mathrm{H}, 4.11 ; \mathrm{N}, 11.17$.

\section{Results and discussion}

In this article, we report the synthesis and biological properties of some thiophene-linked pyrimidopyrimidine derivatives. The chalcones 1a-e used as precursors to synthesise various pyrimidine derivatives have been prepared by refluxing 2-acetylthiophene with aromatic aldehydes in presence of potassium hydroxide in ethanol medium.

The chalcones 1a-e were refluxed with guanidine hydrochloride in presence of $\mathrm{KOH}$ in 1,4dioxane solvent to afford 4-substituted-2-amino-6thiophenopyrimidines $\mathbf{2 a - e}$ in good yield. The formation of $\mathbf{2 a - e}$ were monitored by TLC. In confirmation, 2a exhibited a absorption band at $3330 \mathrm{~cm}^{-1}$ corresponding to NH stretching in its IR spectrum. The ${ }^{1} \mathrm{H}$ NMR spectrum showed a singlet at $\delta 3.88$ due to three protons of $\mathrm{OCH}_{3}$ group and a broad singlet at $\delta 5.09$ due to two protons of $\mathrm{NH}_{2}$ group. Further, a molecular ion peak at $\mathrm{m} / \mathrm{z} 284$ in its mass spectrum is in agreement with the structure.

Pyrimidines 3a-e were prepared by the treatment of 2a-e with acetyl acetone in acetic acid medium. The IR spectrum of compound 3a exhibited a absorption band at $1607 \mathrm{~cm}^{-1}$ due to $\mathrm{C}=\mathrm{N}$ group. The ${ }^{1} \mathrm{H}$ NMR spectrum of compound 3a showed a singlet at $\delta 3.88$ due to three protons of $\mathrm{OCH}_{3}$ group and two singlets at $\delta 2.03$ and $\delta 2.17$ for six protons of two $\mathrm{CH}_{3}$ groups. Further, it showed that a molecular ion peak at $\mathrm{m} / \mathrm{z} 350$ in its mass spectrum is in agreement with the structure.

Compounds 2a-e on refluxed with ethylacetoacetate in presence of catalytic amount of acetic acid produced 2-substituted-4-thiopheno-8-methyl-pyrimido-[1,2- $a]$ pyrimidine-6-ol derivatives $4 \mathbf{a}-\mathbf{e}$. The reactions were monitored by TLC. In confirmation, the IR spectrum of 4a showed a absorption band at $3323 \mathrm{~cm}^{-1}$ due to $\mathrm{OH}$ stretching. The ${ }^{1} \mathrm{H}$ NMR spectrum showed a singlet at $\delta 3.88$ due to three protons of $\mathrm{OCH}_{3}$ group and a singlet at $\delta 9.48$ due to $\mathrm{OH}$ group. Its mass spectra showed a molecular ion peak at $\mathrm{m} / \mathrm{z} 351$ which is in agreement with the structure.

Chlorination of reactive hydroxyl group of compounds $4 \mathbf{a}-\mathbf{e}$ to yield $\mathbf{5 a}-\mathbf{e}$ was done by refluxing $\mathbf{4 a}-\mathbf{e}$ with $\mathrm{POCl}_{3}$ in presence of DMF. Formation of 5a-e was confirmed by the presence of chlorine in elemental analysis. Nucleophilic substitution reactions on compounds 5a-e to replace reactive chlorine were performed by treatment with aniline which resulted in the formation of $\mathbf{6 a - e}$.

Physical properties of synthesised compounds are show in table 1 and some selected compounds were screened for antibacterial and analgesic activity (scheme 1).

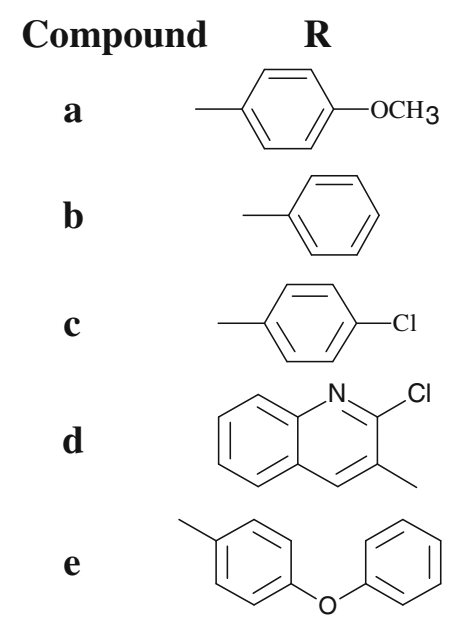

\subsection{Antibacterial activity}

Some selected compounds were screened for their antibacterial activity against Staphylococcus aureus, Escherichia coli, S. paratyphi-A and Bacillus subtilis. The activity was carried out using cupplate agar method. ${ }^{14}$ The zone of inhibition was measured in millimetres. DMF is used as a vehicle. Chloramphenicol and streptomycin were used as standard drugs for comparison. The compounds were tested at $40 \mu \mathrm{g} / \mathrm{mL}$ 
Table 2. Antibacterial activity of synthesised compounds.

\begin{tabular}{|c|c|c|c|c|}
\hline \multirow[b]{2}{*}{ Compound } & \multicolumn{4}{|c|}{ Diameter of zone of inhibition (mm) } \\
\hline & Staphylococcus aureus & Escherichia coli & S. paratyphi-A & Bacillus subtilis \\
\hline $3 \mathbf{a}$ & 13 & 14 & 15 & 12 \\
\hline $3 c$ & 12 & 15 & 10 & 13 \\
\hline 3d & 15 & 12 & 12 & 10 \\
\hline $3 \mathbf{e}$ & 13 & 09 & 10 & 11 \\
\hline $4 a$ & 18 & 17 & 17 & 18 \\
\hline $4 c$ & 14 & 13 & 14 & 18 \\
\hline 4d & 12 & 13 & 14 & 14 \\
\hline $4 e$ & 14 & 12 & 12 & 10 \\
\hline $5 \mathbf{a}$ & 15 & 11 & 16 & 17 \\
\hline $5 c$ & 10 & 12 & 12 & 18 \\
\hline $5 d$ & 14 & 15 & 17 & 11 \\
\hline $5 e$ & 15 & 13 & 08 & 10 \\
\hline $6 \mathbf{a}$ & 18 & 12 & 18 & 17 \\
\hline 6c & 13 & 08 & 11 & 14 \\
\hline 6d & 11 & 10 & 14 & 16 \\
\hline $6 e$ & 15 & 13 & 10 & 13 \\
\hline DMF & 00 & 00 & 00 & 00 \\
\hline Chloramphenicol & 20 & 16 & 21 & 22 \\
\hline
\end{tabular}

concentration. All the synthesised compounds were found to be moderate to poorly active against bacteria. Details of zone of inhibition are presented in table 2.

\subsection{Analgesic activity}

Albino mice of either sex (20-30g) were subjected to acetic-acid-induced writhing test for analgesic activity. ${ }^{15}$ Acetic acid solution $(0.6 \%, 10 \mathrm{~mL} / \mathrm{kg})$ was used to induce writhing in mice. The mice were divided into 11 groups, each consisting of six animals. Analgesic response was assessed by counting the number of abdominal constrictions for 20 min starting $3 \mathrm{~min}$ after the injection of acetic acid solution. Group 1-10 received the suspension of test compounds $(100 \mathrm{mg} / \mathrm{kg}$ dose), respectively, and 11 received the standard drug suspension (Ibuprofen) at the dosage of $100 \mathrm{mg} / \mathrm{kg}$. After $1 \mathrm{~h}$, acetic acid solution was administered intraperitonially and number of abdominal constrictions was recorded for $20 \mathrm{~min}$ starting $3 \mathrm{~min}$ after the injection of acetic acid solution. Analgesic activity was calculated as the percentage of maximum possible effect (\%MPE) and the results are given in table 3 . Compounds 3a, 3d, 6b and $\mathbf{6 d}$ exhibited significant analgesic activity.

Table 3. Analgesic activity of synthesised compounds.

\begin{tabular}{|c|c|c|c|c|}
\hline \multirow[b]{2}{*}{ Compound } & \multirow[b]{2}{*}{ Dose (mg/kg) } & \multicolumn{2}{|c|}{$\begin{array}{c}\text { Mean number of abdominal constrictions } \\
\text { occurred between } 3 \text { and } 20 \text { min }\end{array}$} & \multirow[b]{2}{*}{$\% \mathrm{MPE}$} \\
\hline & & Before drug & After drug & \\
\hline $\mathbf{3 a}$ & 100 & $25.8 \pm 1.2$ & $7.4 \pm 0.92$ & $66.1^{*}$ \\
\hline $3 b$ & 100 & $38.6 \pm 2.1$ & $15.8 \pm 1.43$ & $61.7^{*}$ \\
\hline $3 c$ & 100 & $39.1 \pm 2.0$ & $16.2 \pm 1.40$ & $60.1^{*}$ \\
\hline 3d & 100 & $24.8 \pm 1.2$ & $8.4 \pm 0.92$ & $66.1^{*}$ \\
\hline $3 \mathbf{e}$ & 100 & $40.1 \pm 2.0$ & $15.2 \pm 1.40$ & $60.1^{*}$ \\
\hline $6 \mathbf{a}$ & 100 & $34.1 \pm 2.0$ & $15.1 \pm 0.40$ & $60.1^{*}$ \\
\hline $6 \mathbf{b}$ & 100 & $23.1 \pm 1.5$ & $8.9 \pm 0.82$ & $66.4^{*}$ \\
\hline $6 c$ & 100 & $26.4 \pm 1.6$ & $10.4 \pm 1.3$ & $62.2^{*}$ \\
\hline $6 d$ & 100 & $24.8 \pm 1.2$ & $8.5 \pm 1.92$ & $68.5^{*}$ \\
\hline $6 e$ & 100 & $34.1 \pm 2.0$ & $15.1 \pm 0.40$ & $60.1^{*}$ \\
\hline Ibuprofen & 100 & $47.1 \pm 2.5$ & $11.8 \pm 1.27$ & $75.1^{*}$ \\
\hline
\end{tabular}

Analgesic activity, ${ }^{*} P<0.001$ vs. control; student's $t$-test, $n=6$ 


\section{Conclusion}

New pyrimidopyrimidines prepared are additions to the molecular library. Some compounds have exhibited significant biological activity.

\section{Supplementary information}

Structural data (NMR, IR, mass and elemental analysis) of the rest of the compounds are provided in the supplementary information file. The electronic supporting information can be seen at www.ias.ac.in/chemsci.

\section{Acknowledgements}

Authors are thankful to the Principal, Sahyadri Science College (Autonomous), Shimoga and the Chairman, Department of Chemistry, Sahyadri Science College (Autonomous), Shimoga, for providing necessary laboratory facilities. Authors are also thankful to the Principal, SCS College of Pharmacy, Harapanahalli, for providing facilities to conduct biological activities.

\section{References}

1. Mattew J, Subba Rao A V and Rambhav S P 1984 Curr. Sci. 53(11) 576
2. Yamakawa T, Kagechika H, Kawachi E, Hashimoto Y and Shedo K R 1990 J. Med.Chem. 33(5) 1430

3. Isida S, Matsuda A, Kawamura Y and Yamanaka K 1960 Chromatography (Tokyo) 8146

4. Hogale M B, Dhore N P, Shelar A R and Pawar P K 1986 J. Chem. 255

5. Ahluwalia V K, Nayal L, Kalia N, Bala S and Tahim A K 1987 Indian J. Chem. 26B(4) 384

6. Bhat A K, Bhamana R P, Patel M R, Bellare R A and Deliwala C V 1972 Indian J. Chem. 10(7) 694

7. Ishitsuka H, Ninomiya $\mathrm{Y}$ T, Ohsawa C, Fujiu M and Suhara Y 1982 Antimicrob. Agents Chem-Other. 22(4) 617

8. Ninomiya Y, Shimma N and Ishitsuka H. 1990 Antiviral Res. 13(2) 61

9. Rossman P, Luk K, Cai J, Chen Y, Dermatakis A, Flynn T, Garofalo L, Gillespie P, Goodnow R, Graves B, Harris, W, Huby N, Jackson N, Kabat M, Konzelmann F, Li S, Liu J, Liu W, Lukacs C, Michoud A, Perrotta A and Portland L 2004 Proc. Am. Assoc. Cancer Res. 45

10. Gebauer M G, McKinlay C and Gready J E 2003 Eur. J. Med. Chem. 38(7-8) 719

11. Rahaman A, Rajendra P, Pahani K and Bahrat K 2009 Saudi Pharm. J. 17259

12. Naik T A and Chikhalia K H 2007 E-J. Chem. 460

13. Vishnu J R, Kushwaha D S and Mishra L 1989 Indian J.Chem. 28B 242

14. Barry A L 1976 The antimicrobial susceptibility test: Principle and practice; Illuslea and Febiger, Philadelphia, USA; p. 180

15. Koster M, Anderson and de B 1965 Fed. Proc. 18412 